\title{
Deciphering the Complex Signaling Systems That Regulate Intestinal Epithelial Cell Death Processes and Shedding
}

\section{OPEN ACCESS}

Edited by:

Britta Siegmund,

Charité Universitätsmedizin

Berlin, Germany

Reviewed by:

Susanne M. Krug,

Charité Universitätsmedizin

Berlin, Germany

Luca Pastorelli,

Università degli Studi

di Milano, Italy

*Correspondence:

Alastair J. M. Watson alastair.watson@uea.ac.uk

Specialty section: This article was submitted to Mucosal Immunity, a section of the journal Frontiers in Immunology

Received: 30 May 2017 Accepted: 04 July 2017

Published: 18 July 2017

Citation:

Patterson AM and Watson AJM (2017) Deciphering the Complex Signaling Systems That Regulate Intestinal Epithelial Cell Death

Processes and Shedding.

Front. Immunol. 8:841. doi: 10.3389/fimmu.2017.00841

\author{
Angela M. Patterson ${ }^{1,2}$ and Alastair J. M. Watson ${ }^{1,2 *}$ \\ ${ }^{1}$ Quadram Institute, Norwich Research Park, Norwich, United Kingdom, ${ }^{2}$ Norwich Medical School, University of East Anglia, \\ Norwich, United Kingdom
}

Intestinal epithelial cells play a fundamental role in maintaining homeostasis. Shedding of intestinal cells in a controlled manner is critical to maintenance of barrier function. Barrier function is maintained during this shedding process by a redistribution of tight junctional proteins to facilitate closure of the gap left by the shedding cell. However, despite the obvious importance of epithelial cell shedding to gut health, a central question is how the extrusion of epithelial cells is achieved, enabling barrier integrity to be maintained in the healthy gut and restored during inflammation remains largely unanswered. Recent studies have provided evidence that excessive epithelial cell shedding and loss of epithelial barrier integrity is triggered by exposure to lipopolysaccharide or tumor necrosis factor alpha. Subsequent studies have provided evidence of the involvement of specific cellular components and signaling mechanisms as well as the functionality of microbiota that can be either detrimental or beneficial for intestinal barrier integrity. This review will focus on the evidence and decipher how the signaling systems through which the mucosal immune system and microbiota can regulate epithelial cell shedding and how these mechanisms interact to preserve the viability of the epithelium.

Keywords: intestinal epithelial cells, shedding, apoptosis, necroptosis, pyroptosis

\section{INTRODUCTION}

The intestinal barrier separates the body from the contents of the intestine. It comprises several elements: a mucus layer containing antibacterial peptides covering the luminal surface of the epithelium; the epithelial cell monolayer, junctional proteins, and intraepithelial lymphocytes (IELs); and a subepithelial layer of extracellular matrix and mesenchymal cells including myofibroblasts and fibroblasts. A central element of this intestinal barrier is the epithelial cell (1). In health, there is a continuous shedding of epithelial cells from villus tip or colonic surface as a result of migration of the epithelial cell up the crypt-villus axis from stem cells at the base of the crypt (Figure 1A). The shedding of epithelial cells is counter-balanced by cell division in the crypt region of the villi to maintain homeostasis and a strict single layer epithelium and integrity of the crypt-villus axis (2-4). In physiological conditions, epithelial cells undergo apoptosis during the shedding process though it remains unclear whether apoptosis initiates the shedding process or is secondary to detachment from the basement membrane (3) (Figure 1B). In contrast to physiological cell shedding, tumor necrosis factor alpha $(\mathrm{TNF} \alpha)$-induced apoptotic cell shedding often results in the shedding of multiple adjacent 


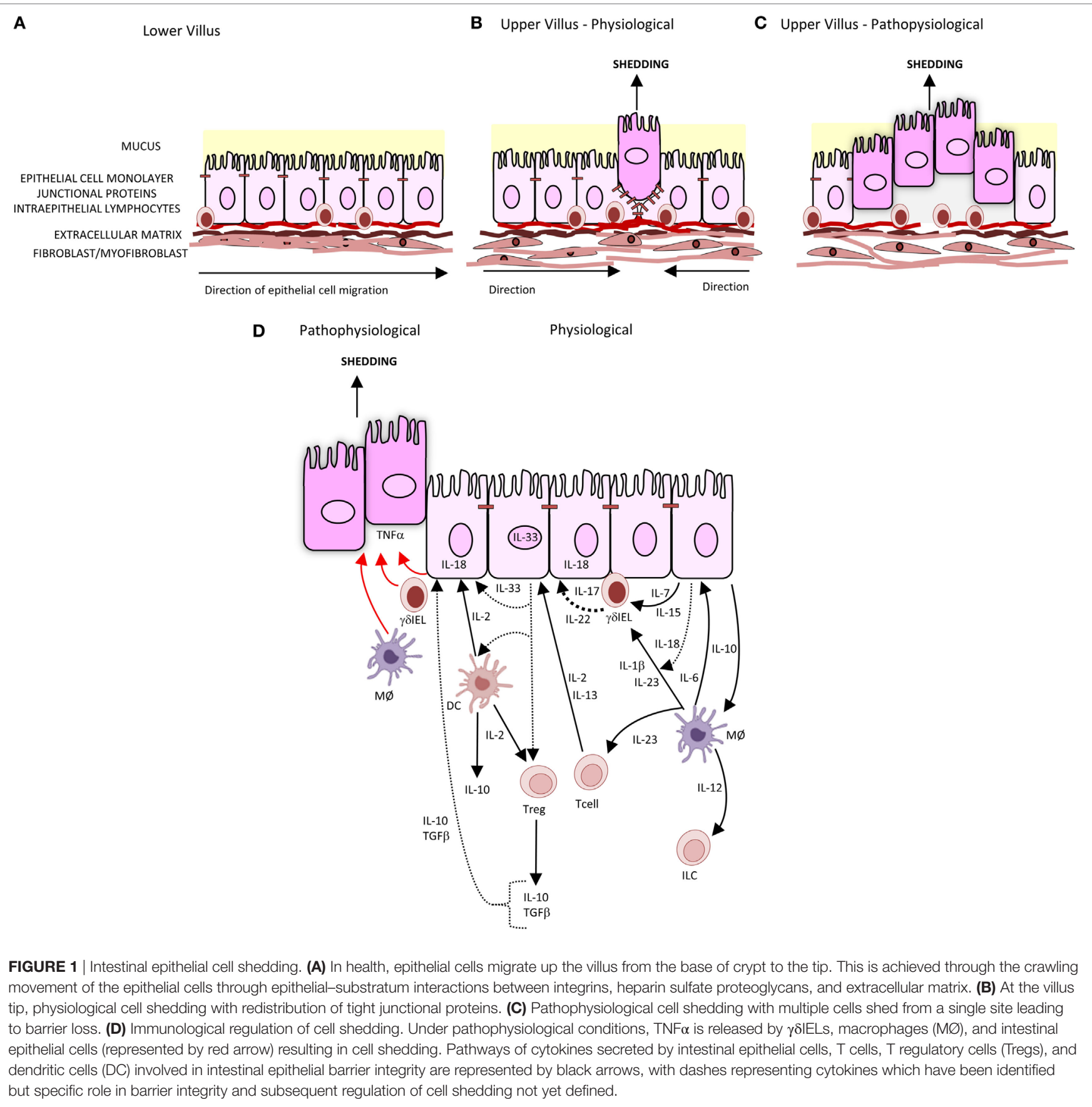

cells causing a breach in the epithelial monolayer too large to be sealed with subsequent loss of barrier function (5) (Figure 1C).

\section{BALANCE OF CELL DIVISION, MIGRATION, AND SHEDDING MAINTAINS BARRIER INTEGRITY}

Epithelial migration is intimately coupled to cell shedding as the two processes must be coordinated to maintain a steady number of epithelial cells on the crypt/villus axis. Until recently, little has been known about the cellular and molecular mechanisms of intestinal epithelial cell migration. This migration is a complex of mechanisms through which each component is intricately balanced. The crawling movement of the epithelial cell along the crypt-villus, axis relies on epithelial cell-substratum interactions regulated by the expression of integrins $(6,7)$, heparan sulfate proteoglycans (8), growth factor (9), cytokine (10), and chemokine receptors (11) as well as extracellular matrix such as laminins and collagen IV (12).

When the epithelial cell is shed, a discontinuity or gap in the villus epithelial monolayer is created, which could potentially 
compromise the epithelial barrier. However, in health, normal cell shedding never causes a breach in the epithelial barrier because this gap is plugged by redistribution of tight junction proteins, which include occludin, $\mathrm{ZO}-1$, and the adherens junction protein E-cadherin (13). This redistribution mechanism of tight junction proteins has also been reported in TNF $\alpha$-induced cells shedding at sites where the gap created by cell shedding has been successfully sealed (14). A further refinement to the extrusion mechanism has been added by the observation that the extrusion of the dying cell is initiated by tension of the dying cell on its neighbors transmitted through cortical contractile actin and a myosin ring at the apex of the dying epithelial cell (15). The redistribution of tight junction proteins results in the modulation of actin filaments, either through actin polymerization with the formation of lamellipodial or actin-myosin interactions forming a ring or a combination of both $(16,17)$. The mechanics of actin polymerization and lamellipodial formation and actin-myosin interactions are not only dependent on GTPases, Rac1 and Rho (18), respectively, and $\operatorname{Cdc} 42$ (19), and trefoil factors $(9,20)$, but also on many factors including regulation of actin-binding proteins such as villin (21-26), the locality and density of the cell shedding $(17,27)$, substratum extracellular matrix (28), gap formation (29), and cytokine signaling pathways. Cytokines such as IFN $\gamma$ and TNF $\alpha$ are involved not only in regulating the remodeling of the junctional proteins (30) but can also be regulated by junctional proteins (31). These cytokines can also act synergistically through the convergence of the $\beta$-catenin signaling pathways. IFN $\gamma$ regulates intestinal epithelial cell proliferation and apoptosis through AKT- $\beta$-catenin pathways and Wnt- $\beta$-catenin signaling pathways, with TNF $\alpha$ activation of the $\beta$-catenin signaling through P13K-AKT and NF- $\mathrm{BB}$ signaling (32).

To untangle these complexities, computational modeling of cell division and migration as well as the use of in vivo and in vitro models using epithelial cell lines and keratinocytes have been used $(4,15,33-38)$. The morphological properties of the cells selected for the cellular models are monolayer formation and contractility including the ability to undergo cell division, morphogenesis, and migration to close gap formation caused by injury $(39,40)$. This has provided an insight into how epithelial cells that line many organs surface operate but how that information can be applied to understand the mechanisms of cell homeostasis and repair within the intestine. Wong and colleagues (33) focused on the migratory positioning and velocity of cells within the crypt and developed a model demonstrating this through the expression and interactions of Eph receptors and ephrins and their regulation cell adhesion. The study highlighted the importance of the cell-cell, cell-substratum, and cytoskeletal organization for maintaining cell migration along the crypt. Parker and colleagues (4) demonstrated how the proliferation of cells within the crypt is the primary force for driving cell migration up the villus and by implication cell shedding. Maintenance of epithelial homeostasis and response to injury is regulated through the expression of signal transduction pathways such as WNT $(41,42)$ and NOTCH $(43,44)$ and JAK/STAT pathways and interaction with cytokines. The pathways are highly complex with multiple interactions. For example, JAK3/IL-2/IL2R can result in regulation of villin (45), the STAT5 pathway regulates cellular proliferation of intestinal stem cells (46), and STAT3/IL-22/IL-22R pathways regulate cellular regeneration (47).

The factors determining whether an individual intestinal epithelial cell is shed is not understood. In epithelial cells of the Zebrafish fin, it has been found that the overcrowding and physical stretching of the epithelial cell as it reaches the tip of the fin is sensed by the stretch activated cation selected ion channel Piezo-1. This stimulates extrusion of the epithelial cells through sphingosine 1-phosphate signaling and Rho kinase (37). Furthermore, it has recently been demonstrated that cellular crowding sensed through Piezol increases epithelial proliferation in the Zebrafish larvae to preserve overall epithelial homeostasis (38). It is not known whether similar mechanisms occur in the mammalian intestine.

A recent study has suggested that the actin regulatory protein villin might direct the site of intestinal epithelial apoptotic cell shedding on the villus. It regulates cell turnover through the regulation of caspase- 3 and caspase- 9 apoptotic pathways and regulating actin polymerization and depolymerization (21). Recent data have demonstrated that villin is not only anti-apoptotic but also has pro-apoptotic functions. This function is dependent on the cleavage of villin by proteolytic enzymes. These enzymes, such as meprin, a matrix metalloproteinase, cleaves the villin into fragments, of which the $\mathrm{N}$-terminal villin fragment is pro-apoptotic at the villus tip and can reorganize the actin filaments resulting in cell shedding (48).

\section{TYPES OF CELL DEATH INDUCING CELL SHEDDING}

A number of types of cell death have been reported intestinal epithelial cells. TNF $\alpha$-induced apoptotic cell shedding has been studied in some detail. However, it is becoming appreciated that pyroptosis and necroptosis also play a role in intestinal epithelial cell injury (Table 1).

Apoptosis is mediated through either intrinsic or extrinsic pathways $(49,50)$. In the intrinsic pathway, cellular injury triggers the release of cytochrome $c$ from mitochondria to form an apoptosome in cytosol, comprising cytochrome $c$, apopotic protease factor 1 (APAF-1), and procaspase-9, which triggers activation of a cascade of proteases called caspases which kill the cell. In the extrinsic pathway, apoptosis is triggered by the binding of external proteins such as TNF $\alpha$ or FasL to their cognate receptors expressed on the surface of the target cell. The binding

TABLE 1 | Intestinal epithelial cell death processes involved in cell shedding (49-56).

\begin{tabular}{llll}
\hline Apoptosis & Necroptosis & Pyroptosis & Necrosis \\
\hline Caspase-3 +ve & Caspase-3 -ve & Caspase-3 -ve & Caspase-3 -ve \\
Caspase-1 -ve & Caspase-1 +ve & Caspase-1 +ve & Caspase-1 -ve \\
Tunnel +ve & Tunnel +ve & Caspase-11 (mouse) +ve & Annexin V +ve \\
Annexin V +ve & RIP3 +ve & Caspase-4 (human) +ve & Propidium \\
& & & iodide +ve \\
Propidium iodide -ve RIPK-3 +ve & Caspase-5 (human) +ve & Tunnel +ve/-ve \\
Caspase-8 +ve/-ve & Caspase-8 +ve & Gasdermin D +ve &
\end{tabular}


of the ligand to the receptor stimulates the activation of caspase- 8 through a series of intermediate proteins to cause apoptosis (51). In a mouse model of rapid small intestinal epithelial cell shedding and apoptosis developed by Watson and colleagues $(5,14,16,52)$, it has been demonstrated that TNF $\alpha$ release in the lamina propria caused cell shedding via the TNF receptor 1 . The TNF $\alpha$ then activates NF- $\kappa \mathrm{B}$ pathway. A differential sensitivity of cell shed-

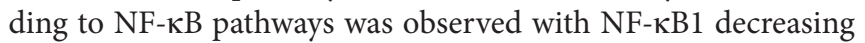
sensitivity, while NF- $\kappa \mathrm{B} 2$ increases the sensitivity of epithelial cell shedding to lipopolysaccharide (LPS). Studies of the mechanism of cell shedding have shown that activation of caspase- 3 by TNF $\alpha$ cleaves and activates Rho-associated protein kinase (ROCK1) and the phosphorylation of myosin light chains resulting in the membrane blebbing formation in apoptotic cells. Inhibition of either of these enzyme activities arrests cell shedding after its initiation such that the shedding process is incomplete $(14,15)$. In addition, it has been reported that synthesis of sphingosine-1-phosphate by dying cell binds to the $\mathrm{S} 1 \mathrm{P}(2)$ receptor in neighboring cells to activate myosin contraction to extrude the dying cell out of the epithelial monolayer (53).

Ubiquitin-dependent signaling activated by pattern recognition receptors (PRRs) mediates activation of NF- $\kappa \mathrm{B}$ transcription factors as well as the MAP kinases p38 and JNK. NF- $\kappa B 1$ and MAPK expression reduces cell shedding, while NF- $\kappa \mathrm{B} 2$ increases shedding. NF- $\kappa \mathrm{B}$ is required for expression of downstream cytokines and chemokines such as TNF $\alpha$, IL-6, IL-1 $\beta$, and CCL20. Data to date demonstrate an action of PRRs in intestinal inflammation and epithelial apoptosis; therefore, it is plausible that aspects of the innate immune system may regulate cell shedding.

The mode of cell death is dependent on the activation of various cellular signaling pathways after initial cytokine stimulation. The differences have been highlighted recently by the groups of Günther et al. and Rauch et al. $(52,54)$. In the absence or inactivation of caspase-8, TNF $\alpha$ induces necroptosis at the base of the crypt with loss of Paneth cells via RIP-3 kinase. This is relevant to Crohn's disease as necroptosis occurs in the intestinal crypt (55). Caspase- 8 acts as a type of switch. When functional, it initiates apoptosis which is a benign form of cell death from the point of view of the whole animal. However, when caspase- 8 is not functional, cell death still occurs but via RIP3-kinase-dependent necroptosis which affects multiple cell types in a number of organs with increased mortality (52). Rauch and colleagues demonstrated the induction of apoptosis through caspase- 8 activation and interaction with inflammasomes. Inflammasomes in inflammation regulate cell death through the activation of caspase-1 resulting in the expulsion of cells or pyroptosis. This mode of action can be induced through microbial ligands binding to NAIP family members of the inflammasome complex (56).

\section{BACTERIAL ENTRY AND EPITHELIAL CELL SHEDDING}

When shedding of multiple adjacent apoptotic cells creates gaps that are too large to be plugged by the redistribution of apical junctional proteins, as frequently occurs when TNF concentrations are high, the epithelial barrier is breached at the shedding site (14). In clinical studies using confocal endomicroscopy, this has been shown to trigger relapse of inflammatory bowel disease (14). This allows the entry of bacteria such as Listeria (57), antigens, and toxins from the lumen, which act to amplify inflammatory reactions within the lamina propria. However, apoptotic cell shedding can be an important mechanism to expel epithelial cells invaded by pathogenic bacteria and thereby reducing the chance of bacterial colonization as well as localizing inflammatory reactions. To this end, pathogenic bacteria, such as Shigella, Citrobacter, and Salmonella, have evolved to prevent cell shedding through the production of bacterial effector proteins. One effector protein secreted by these bacteria is the protein OspE that enhances epithelial cell-matrix interactions through binding of the integrin-linked kinase of the epithelial cell to the cells actin cytoskeleton resulting in increased integrin expression and thereby increased focal adhesions to the extracellular matrix $(58,59)$. This evasive mechanism results in bacterial colonization and inflammatory reactions within the intestine. However, this bacterial evasive mechanism relies on an interaction between the epithelial cell and underlying matrix via the integrin-linked kinase, which can only take place in the crypt and lower villus $(58,59)$. Although Salmonella can inhibit cell shedding, and thereby interfere with the epithelial cell response to bacterial infection, it is not the only mechanism of defense by the epithelial cells. This mechanism is through the formation of inflammasomes complexes, caspase- 1 activation, and the production of cytokines and ultimately pyroptotic cell death (60), although recent work has demonstrated that this mechanism can result in apoptotic and pyroptotic cell death via caspase- 8 activation $(52,61)$.

\section{REGULATION OF CELL SHEDDING BY THE MUCOSAL IMMUNE SYSTEM}

Intraepithelial lymphocytes within the epithelial monolayer have normally been associated with celiac disease; however, recent date indicate that they may have a central role in epithelial barrier function. Interestingly, recent data from Edelblum and colleagues (62) have demonstrated that $\gamma \delta$-IELs can migrate along the epithelium by an occludin-dependent mechanism. Given that occludin is redistributed to surround the shedding cell during expulsion, it is an attractive hypothesis that the IELs might participate in the regulation of cell shedding through occludin-dependent mechanisms. IELs could initiate epithelial cell restitution by stimulating epithelial cell migration into the gap created by cell shedding. They might also signal to the epithelial cells adjacent to the shedding cells to stimulate cytoskeletal reorganization. Migration of IELs within the epithelium can also be regulated by the chemokine-chemokine receptor interaction such as CCL25-CCR9 (63) as well as through the expression of chemokine receptors CCR5, CX3CR1, and CCR3 (64). Chemokine regulated migration of IELs could potentially direct IELs to sites of cell shedding. IELs could potentially also regulate the responses of other cell populations, such as subepithelial myofibroblasts and macrophages. Such subepithelial 
responses may be important in the prevention of paracellular migration of opportunistic pathogenic $(65,66)$ and commensal bacteria (67).

Both innate and adaptive immunity are hypothesized to regulate or respond to cell shedding. Within the innate immune system that comprises monocytes/macrophages, dendritic cells, innate lymphoid cells, and epithelial cells, microbes are recognized by PRRs such as toll-like receptors and nucleotide oligomerization domains (NODs) expressed on these cells. We have found that Bifidobacterium breve significantly reduce LPS and TNF $\alpha$-induced epithelial cell shedding through a NOD2dependent mechanism that requires the exopolysaccharide of the Bifidobacteria (68).

Although there that been innumerable studies of components of the adaptive and innate immune systems regulating mucosal damage, only few studies that specifically investigated the regulation of epithelial cell shedding (Figure 1D). Mechanistic studies have demonstrated a role for $\mathrm{T}$ regulatory cells in both adaptive and innate immunity. Production of cytokines IL-10, IL-4, and IL-13 is critical for suppression of pro-inflammatory cytokine responses from other immune cells such as monocytes/ macrophage and thus could reduce TNF $\alpha$-induced cell shedding. IL-13 also downregulates the effects of LPS-induced endotoxin. Its effects of LPS-induced cell shedding have not been reported. IL-13 has been shown to modulate intestinal epithelial tight junctions, claudin-2, and apoptosis and therefore potentially cell shedding (69). The cytokines, such as IL-10, IL-21, IL-22, IL-23, and IL-6, activate STAT3 and, in addition to IL-13, are also regulated through STAT3. Inhibition of STAT3 blocks the antiapoptotic activity of IL-6 (70); therefore, it is possible that inhibition of STAT3 may also disrupt the immunosuppressive action of

\section{REFERENCES}

1. Peterson LW, Artis D. Intestinal epithelia cells: regulators of barrier function and immune homeostasis. Nat Rev Immunol (2014) 14:141-53. doi:10.1038/ nri3608

2. Barker N, van Es JH, Kuipers J, Kujala P, van den Born M, Cozijnsen M, et al. Identification of stem cells in small intestine and colon by marker gene Lgr5. Nature (2007) 449:1003-7. doi:10.1038/nature06196

3. Watson AJ, Hall LJ, Hughes KR. Cell shedding: old questions answered. Gastroenterology (2012) 143:1389-91. doi:10.1053/j.gastro.2012.09.025

4. Parker A, Maclaren OJ, Fletcher AG, Muraro D, Kreuzaler PA, Byrne HM, et al. Cell proliferation within the small intestinal crypts is the principal driving force for cell migration on villi. FASEB J (2017) 31:636-47. doi:10.1096/ff. 201601002

5. Kiesslich R, Duckworth CA, Moussata D, Gloeckner A, Lim LG, Goetz M, et al. Local barrier dysfunction identified by confocal laser endomicroscopy predicts relapse in inflammatory bowel disease. Gut (2012) 61:1146-53. doi:10.1136/gutjnl-2011-300695

6. Rankin CR, Hilgarth RS, Leoni G, Kwon M, Den Beste KA, Parkos CA, et al. Annexin A2 regulates $\beta 1$ integrin internalization and intestinal epithelial cell migration. J Biol Chem (2013) 288:15229-39. doi:10.1074/jbc.M112.440909

7. Kaemmerer E, Kuhn P, Schneider U, Clahsen T, Jeon MK, Klaus C, et al. Beta-7 integrin controls enterocyte migration in the small intestine. World J Gastroenterol (2015) 21:1759-64. doi:10.3748/wjg.v21.i6.1759

8. Wang H, Jin H, Beauvais DM, Rapraeger AC. Cytoplasmic domain interactions of syndecan- 1 and syndecan- 4 with $\alpha 6 \beta 4$ integrin mediate human epidermal growth factor receptor (HER1 and HER2)-dependent motility and survival. J Biol Chem (2014) 289:30318-32. doi:10.1074/jbc.M114.586438
IL-13 and IL-10, which in turn modulates TNF $\alpha$ production and thereby epithelial shedding and apoptosis.

\section{CONCLUSION}

Important advances have been made in our understanding of the maintenance of epithelial integrity in health and disease. The mechanisms of extrusion of epithelial cells are now being unraveled though it remains unclear what the determinants are of an individual epithelial cell being shed. A number of studies of cytokines and chemokines have demonstrated their importance in epithelial integrity they have not specifically addressed their role in the regulation of cell shedding itself. It is now appreciated that a number of types of cell death can trigger epithelial extrusion with increasing examples of necroptosis and pyroptosis being reported in addition to apoptosis. There is now also an increasing understanding that epithelial cell shedding can be a protective mechanism against infection through expulsion of invading pathogens. Further studies are likely to reveal therapeutic targets for inflammatory and infective bowel disease.

\section{AUTHOR CONTRIBUTIONS}

AP collected and analyzed data, drafted the manuscript, and contributed toward and approved the final manuscript. AW drafted the manuscript and contributed toward and approved the final manuscript.

\section{FUNDING}

This work is supported by BBSRC grant BB/J004529/1.
9. Dürer U, Hartig R, Bang S, Thim L, Hoffmann W. TFF3 and EGF induce different migration patterns of intestinal epithelial cells in vitro and trigger increased internalization of E-cadherin. Cell Physiol Biochem (2007) 20:329-46. doi:10.1159/000107519

10. Brand S, Beigel F, Olszak T, Zitzmann K, Sören T, Eichhorst J-M. L-22 is increased in active Crohn's disease and promotes proinflammatory gene expression and intestinal epithelial cell migration. Am J Physiol Gastrointest Liver Physiol (2006) 290:G827-38. doi:10.1152/ ajpgi.00513.2005

11. Smith JM, Johanesen PA, Wendt MK, Binion DG, Dwinell MB. CXCL12 activation of CXCR4 regulates mucosal host defense through stimulation of epithelial cell migration and promotion of intestinal barrier integrity. Am J Physiol Gastrointest Liver Physiol (2005) 288:G316-26. doi:10.1152/ ajpgi.00208.2004

12. Begnaud S, Chen T, Delacour D, Mège RM, Ladoux B. Mechanics of epithelial tissues during gap closure. Curr Opin Cell Biol (2016) 42:52-62. doi:10.1016/j. ceb.2016.04.006

13. Guan Y, Watson AJ, Marchiando AM, Bradford E, Shen L, Turner JR, et al. Redistribution of the tight junction protein $\mathrm{ZO}-1$ during physiological shedding of mouse intestinal epithelial cells. Am J Physiol Cell Physiol (2011) 300:C1404-14. doi:10.1152/ajpcell.00270.2010

14. Marchiando AM, Shen L, Graham WV, Edelblum KL, Duckworth CA, Guan Y, et al. The epithelial barrier is maintained by in vivo tight junction expansion during pathologic intestinal epithelial shedding. Gastroenterology (2011) 140: 1208-18.e1-2. doi:10.1053/j.gastro.2011.01.004

15. Kuipers D, Mehonic A, Kajita M, Peter L, Fujita Y, Duke T, et al. Epithelial repair is a two-stage process driven first by dying cells and then by their neighbours. J Cell Sci (2014) 127:1229-41. doi:10.1242/jcs.138289 
16. Williams JM, Duckworth CA, Watson AJ, Frey MR, Miguel JC, Burkitt MD, et al. A mouse model of pathological small intestinal epithelial cell apoptosis and shedding induced by systemic administration of lipopolysaccharide. Dis Model Mech (2013) 6(6):1388-99. doi:10.1242/dmm.013284

17. Kocgozlu L, Saw TB, Le AP, Yow I, Shagirov M, Wong E, et al. Epithelial cell packing induces distinct modes of cell extrusions. Curr Biol (2016) 26(21):2942-50. doi:10.1016/j.cub.2016.08.057

18. Arnold TR, Stephenson RE, Miller AL. Rho GTPases and actomyosin: partners in regulating epithelial cell-cell junction structure and function. Exp Cell Res (2017). doi:10.1016/j.yexcr.2017.03.053

19. Melendez J, Liu M, Sampson L, Akunuru S, Han X, Vallance J, et al. Cdc42 coordinates proliferation, polarity, migration, and differentiation of small intestinal epithelial cells in mice. Gastroenterology (2013) 145(4):808-19. doi:10.1053/j.gastro.2013.06.021

20. Le J, Zhang DY, Zhao Y, Qiu W, Wang P, Sun Y. ITF promotes migration of intestinal epithelial cells through crosstalk between the ERK and JAK/STAT3 pathways. Sci Rep (2016) 6:33014. doi:10.1038/srep33014

21. Wang Y, Srinivasan K, Siddiqui MR, George SP, Tomar A, Khurana S. A novel role for villin in intestinal epithelial cell survival and homeostasis. J Biol Chem (2008) 283:9454-64. doi:10.1074/jbc.M707962200

22. Patnaik S, George SP, Pham E, Roy S, Singh K, Mariadason JM, et al. By moonlighting in the nucleus, villin regulates epithelial plasticity. Mol Biol Cell (2016) 27:535-48. doi:10.1091/mbc.E15-06-0453

23. Lhocine N, Arena ET, Bomme P, Ubelmann F, Prévost MC, Robine S, et al. Apical invasion of intestinal epithelial cells by Salmonella typhimurium requires villin to remodel the brush border actin cytoskeleton. Cell Host Microbe (2015) 17(2):164-77. doi:10.1016/j.chom.2014.12.003

24. Solaymani-Mohammadi S, Singer SM. Regulation of intestinal epithelial cell cytoskeletal remodeling by cellular immunity following gut infection. Mucosal Immunol (2013) 6(2):369-78. doi:10.1038/mi.2012.80

25. Ubelmann F, Chamaillard M, El-Marjou F, Simon A, Netter J, Vignjevic D, et al. Enterocyte loss of polarity and gut wound healing rely upon the F-actinsevering function of villin. Proc Natl Acad Sci U S A (2013) 110:E1380-9. doi:10.1073/pnas. 1218446110

26. Cheung R, Kelly J, Macleod RJ. Regulation of villin by wnt5a/ror2 signaling in human intestinal cells. Front Physiol (2011) 2:58. doi:10.3389/fphys.2011.00058

27. Anon E, Serra-Picamal X, Hersen P, Gauthier NC, Sheetz MP, Trepat X, et al. Cell crawling mediates collective cell migration to close undamaged epithelial gaps. Proc Natl Acad Sci U S A (2012) 109:10891-6. doi:10.1073/ pnas.1117814109

28. Brugués A, Anon E, Conte V, Veldhuis JH, Gupta M, Colombelli J, et al. Forces driving epithelial wound healing. Nat Phys (2014) 10:683-90. doi:10.1038/ nphys 3040

29. Ravasio A, Cheddadi I, Chen T, Pereira T, Ong HT, Bertocchi C, et al. Gap geometry dictates epithelial closure efficiency. Nat Commun (2015) 6:7683. doi: $10.1038 /$ ncomms 8683

30. Capaldo CT, Farkas AE, Hilgarth RS, Krug SM, Wolf MF, Benedik JK, et al. Proinflammatory cytokine-induced tight junction remodeling through dynamic self-assembly of claudins. Mol Biol Cell (2014) 25:2710-9. doi:10.1091/mbc.E14-02-0773

31. Van Itallie CM, Fanning AS, Holmes J, Anderson JM. Occludin is required for cytokine-induced regulation of tight junction barriers. J Cell Sci (2010) 123:2844-52. doi:10.1242/jcs.065581

32. Nava P, Koch S, Laukoetter MG, Lee WY, Kolegraff K, Capaldo CT, et al. Interferon- $\gamma$ regulates intestinal epithelial homeostasis through converging $\beta$-catenin signaling pathways. Immunity (2010) 32(3):392-402. doi:10.1016/j. immuni.2010.03.001

33. Wong SY, Cham KH, Lim CT, Matsudaira P. Computational model of cell positioning: directed and collective migration in the intestinal crypt epithelium. J R Soc Interface (2010) 7:S351-63. doi:10.1098/rsif.2010.0018.focus

34. Dunn S-J, Näthke IS, Osborne JM. Computational models reveal a passive mechanism for cell migration in the crypt. PLoS One (2013) 8:e80516. doi:10.1371/journal.pone.0080516

35. Niculescu I, Textor J, de Boer RJ. Crawling and gliding: a computational model for shape-driven cell migration. PLoS Comput Biol (2015) 11:e1004280. doi:10.1371/journal.pcbi.1004280

36. Albert PJ, Schwarz US. Dynamics of cell ensembles on adhesive micropatterns: bridging the gap between single cell spreading and collective cell migration. PLoS Comput Biol (2016) 12(4):e1004863. doi:10.1371/journal.pcbi.1004863
37. Eisenhoffer GT, Loftus PD, Yoshigi M, Otsuna H, Chien CB, Morcos PA, et al. Crowding induces live cell extrusion to maintain homeostatic cell numbers in epithelia. Nature (2012) 484:546-9. doi:10.1038/nature10999

38. Gudipaty SA, Lindblom J, Loftus PD, Redd MJ, Edes K, Davey CF, et al. Mechanical stretch triggers rapid epithelial cell division through Piezol. Nature (2017) 543:118-21. doi:10.1038/nature21407

39. Farooqui R, Fenteany G. Multiple rows of cells behind an epithelial wound edge extend cryptic lamellipodia to collectively drive cell-sheet movement. J Cell Sci (2005) 118:51-63. doi:10.1242/jcs.01577

40. George SP, Chen H, Conrad JC, Khurana S. Regulation of directional cell migration by membrane-induced actin bundling. J Cell Sci (2013) 126:312-26. doi: $10.1242 /$ jcs. 116244

41. Du H, Nie Q, Holmes WR. The interplay between Wnt mediated expansion and negative regulation of growth promotes robust intestinal crypt structure and homeostasis. PLoS Comput Biol (2015) 11(8):e1004285. doi:10.1371/ journal.pcbi.1004285

42. Koch S, Nava P, Addis C, Kim W, Denning TL, Li L, et al. The Wnt antagonist Dkk1 regulates intestinal epithelial homeostasis and wound repair. Gastroenterology (2011) 141(1):259-68.e8. doi:10.1053/j.gastro.2011. 03.043

43. VanDussen KL, Carulli AJ, Keeley TM, Patel SR, Puthoff BJ, Magness ST, et al. Notch signaling modulates proliferation and differentiation of intestinal crypt base columnar stem cells. Development (2012) 139:488-97. doi:10.1242/ dev.070763

44. Chen G, Zhang Z, Cheng Y, Xiao W, Qiu Y, Yu M, et al. The canonical notch signaling was involved in the regulation of intestinal epithelial cells apoptosis after intestinal ischemia/reperfusion injury. Int J Mol Sci (2014) 15:7883-96. doi:10.3390/ijms15057883

45. Kumar N, Mishra J, Narang VS, Waters CM. Janus kinase 3 regulates interleukin 2-induced mucosal wound repair through tyrosine phosphorylation of villin. J Biol Chem (2007) 282:30341-5. doi:10.1074/jbc.C600319200

46. Gilbert S, Nivarthi H, Mayhew CN, Lo YH, Noah TK, Vallance J, et al. Activated STAT5 confers resistance to intestinal injury by increasing intestinal stem cell proliferation and regeneration. Stem Cell Reports (2015) 4:209-25 doi:10.1016/j.stemcr.2014.12.004

47. Lindemans CA, Calafiore M, Mertelsmann AM, O'Connor MH, Dudakov JA, Jenq RR, et al. Interleukin-22 promotes intestinal-stem-cellmediated epithelial regeneration. Nature (2015) 528:560-4. doi:10.1038/ nature 16460

48. Wang Y, George SP, Roy S, Pham E, Esmaeilniakooshkghazi A, Khurana S. Both the anti- and pro-apoptotic functions of villin regulate cell turnover and intestinal homeostasis. Sci Rep (2016) 6:35491. doi:10.1038/srep35491

49. Elmore S. Apoptosis: a review of programmed cell death. Toxicol Pathol (2007) 35:495-516. doi:10.1080/01926230701320337

50. Taylor RC, Cullen SP, Martin SJ. Apoptosis: controlled demolition at the cellular level. Nat Rev Mol Cell Biol (2008) 9:231-41. doi:10.1038/nrm2312

51. Günther C, Neumann H, Neurath MF, Becker C. Apoptosis, necrosis and necroptosis: cell death regulation in the intestinal epithelium. Gut (2013) 62:1062-71. doi:10.1136/gutjnl-2011-301364

52. Günther C, Buchen B, He GW, Hornef M, Torow N, Neumann H, et al. Caspase- 8 controls the gut response to microbial challenges by Tnf- $\alpha$ dependent and independent pathways. Gut (2015) 64:601-10. doi:10.1136/ gutjnl-2014-307226

53. Gu Y, Forostyan T, Sabbadini R, Rosenblatt J. Epithelial cell extrusion requires the sphingosine-1-phosphate receptor 2 pathway. J Cell Biol (2011) 193:667-76. doi:10.1083/jcb.201010075

54. Rauch I, Deets KA, Ji DX, von Moltke J, Tenthorey JL, Lee AY, et al. NAIPNLRC4 inflammasomes coordinate intestinal epithelial cell expulsion with eicosanoid and IL-18 release via activation of caspase-1 and -8. Immunity (2017) 46:649-59. doi:10.1016/j.immuni.2017.03.016

55. Günther C, Martini E, Wittkopf N, Amann K, Weigmann B, Neumann H, et al. Caspase- 8 regulates TNF- $\alpha$-induced epithelial necroptosis and terminal ileitis. Nature (2011) 477:335-9. doi:10.1038/nature10400

56. Kofoed EM, Vance RE. Innate immune recognition of bacterial ligands by NAIPs determines inflammasome specificity. Nature (2011) 477:592-5. doi:10.1038/nature10394

57. Pentecost M, Otto G, Theriot JA, Amieva MR. Listeria monocytogenes invades the epithelial junctions at sites of cell extrusion. PLoS Pathog (2006) 2(1):e3. doi:10.1371/journal.ppat.0020003 
58. Kim M, Ogawa M, Fujita Y, Yoshikawa Y, Nagai T, Koyama T, et al. Bacteria hijack integrin-linked kinase to stabilize focal adhesions and block cell detachment. Nature (2009) 459:578-82. doi:10.1038/nature07952

59. Assi K, Bergstrom K, Vallance B, Owen D, Salh B. Requirement of epithelial integrin-linked kinase for facilitation of Citrobacter rodentium-induced colitis. BMC Gastroenterol (2013) 13:137. doi:10.1186/1471-230X-13-137

60. Sellin ME, Müller AA, Felmy B, Dolowschiak T, Diard M, Tardivel A, et al. Epithelium-intrinsic NAIP/NLRC4 inflammasome drives infected enterocyte expulsion to restrict Salmonella replication in the intestinal mucosa. Cell Host Microbe (2014) 16:237-48. doi:10.1016/j.chom.2014.07.001

61. Sagulenko V, Thygesen SJ, Sester DP, Idris A, Cridland JA, Vajjhala PR, et al. AIM2 and NLRP3 inflammasomes activate both apoptotic and pyroptotic death pathways via ASC. Cell Death Differ (2013) 20:1149-60. doi:10.1038/ cdd. 2013.37

62. Edelblum KL, Shen L, Weber CR, Marchiando AM, Clay BS, Wang Y, et al. Dynamic migration of $\gamma \delta$ intraepithelial lymphocytes requires occludin. Proc Natl Acad Sci U S A (2012) 109:7097-102. doi:10.1073/pnas.1112519109

63. Ericsson A, Svensson M, Arya A, Agace WW. CCL25/CCR9 promotes the induction and function of CD103 on intestinal intraepithelial lymphocytes. Eur J Immunol (2004) 34:2720-9. doi:10.1002/eji.200425125

64. Agace WW, Roberts AI, Wu L, Greineder C, Ebert EC, Parker CM. Human intestinal lamina propria and intraepithelial lymphocytes express receptors specific for chemokines induced by inflammation. Eur J Immunol (2001) 30:819-26. doi:10.1002/1521-4141(200003)30:3<819::AID-IMMU819>3.3.CO;2-P

65. Pentecost M, Kumaran J, Ghosh P, Amieva MR. Listeria monocytogenes internalin B activates junctional endocytosis to accelerate intestinal invasion. PLoS Pathog (2010) 6(5):e1000900. doi:10.1371/journal.ppat.1000900

66. Boehm M, Hoy B, Rohde M, Tegtmeyer N, Baek KT, Oyarzabal OA, et al. Rapid paracellular transmigration of Campylobacter jejuni across polarized epithelial cells without affecting TER: role of proteolytic-active
HtrA cleaving E-cadherin but not fibronectin. Gut Pathog (2012) 4(1):3. doi:10.1186/1757-4749-4-3

67. Pruteanu M, Shanahan F. Digestion of epithelial tight junction proteins by the commensal Clostridium perfringens. Am J Physiol Gastrointest Liver Physiol (2013) 305:G740-8. doi:10.1152/ajpgi.00316.2012

68. Hughes KR, Harnisch LC, Alcon-Giner C, Mitra S, Wright CJ, Ketskemety $\mathrm{J}$, et al. Bifidobacterium breve reduces apoptotic epithelial cell shedding in an exopolysaccharide and MyD88-dependent manner. Open Biol (2017) 7(1):160155. doi:10.1098/rsob.160155

69. Heller F, Florian P, Bojarski C, Richter J, Christ M, Hillenbrand B, et al. Interleukin-13 is the key effector Th2 cytokine in ulcerative colitis that affects epithelial tight junctions, apoptosis, and cell restitution. Gastroenterology (2005) 129:550-64. doi:10.1053/j.gastro.2005.05.002

70. Hodge DR, Hurt EM, Farrar WL. The role of IL-6 and STAT3 in inflammation and cancer. Eur J Cancer (2005) 41:2502-12. doi:10.1016/j.ejca.2005.08.016

Conflict of Interest Statement: The authors declare that the research was conducted in the absence of any commercial or financial relationships that could be construed as a potential conflict of interest.

The reviewer, SK, and handling Editor declared their shared affiliation, and the handling Editor states that the process nevertheless met the standards of a fair and objective review.

Copyright (C) 2017 Patterson and Watson. This is an open-access article distributed under the terms of the Creative Commons Attribution License (CC BY). The use, distribution or reproduction in other forums is permitted, provided the original author(s) or licensor are credited and that the original publication in this journal is cited, in accordance with accepted academic practice. No use, distribution or reproduction is permitted which does not comply with these terms. 